\title{
THE LAST ILLNESS OF HEROD THE GREAT, KING OF JUDAEA
}

by

\author{
A. T. SANDISON
}

\section{INTRODUCTION}

FOR most of us living in the second half of the twentieth century, Herod the Great remains a shadowy figure who is recalled only at Christmas when we read of his massacre of the innocents (Matt. 2:16). He is even confused with Herod Agrippa who persecuted the Church and also died a miserable death (Acts 12:23). Our ancestors, however, were better informed since they often kept, on the same shelf as the Family Bible, a copy of Whiston's Works of Flavius Josephus. Josephus in his Jewish Antiquities and Jewish War gives a vivid account of the life of Herod the Great.

Flavius Josephus, an aristocratic Jew, was born Joseph ben Mathias in A.D. 37-38. He took part in the Jewish revolt in Galilee and was captured at Iotapata by the Romans in A.D. 67. Josephus prophesied that the victor, Vespasian, would rise to Imperial power and Vespasian was, in fact, raised to the purple in A.D. 69. Josephus accompanied Titus to the Siege of Jerusalem and thereafter spent 30 years or more in Rome, taking citizenship there. After the death of Titus he became historian and apologist of the Jewish nation.

Thackeray (1929) assesses him as an egoist, self-centred and time serving, and a flatterer of his Roman patrons. He had nevertheless great merits and contributed much to learning and history. His Contra Apionem is a fine apologia for Judaism.

Our main sources of information concerning Herod the Great are his histories and these in turn are based on works of Nicolas of Damascus, a close relative of Herod and friend of the Emperor Augustus. In Antiquities Josephus, unlike Nicolas of Damascus, severely censures the crimes of Herod. The story of Herod is told twice over, rather briefly and analytically in Wars and chronologically in three full books of Antiquities. Thackeray believes that in the main Josephus' narrative is trustworthy.

\section{THE KING}

After the conquests of Alexander the Great the Levant was progressively hellenized; Palestine at first came under Antiochus, then Ptolemy. John Hyrcanus annexed Samaria and conquered Idumaea. While Hyrcanus' grandson, Hyrcanus II, was Ethnarch, his vizier Antipater administered Judaea. In 47 B.C. Anthony appointed Antipater's sons, Phasael and Herod, to be Governors of Jerusalem and Galilee respectively.

When he was appointed to Galilee at the age of 26 , Herod was well-equipped to be a leader. Unfortunately, from boyhood he had been habituated to treachery, sedition, conspiracy, rebellion, battle, murder and sudden death. He might be faithful and loyal to a relation or friend but yet could murder his own kin (Jones, 1938, Perowne, 1956).

In 40 B.C. his brother Phasael was murdered by the Parthians. At this time Roman 


\section{A.T. Sandison}

politics were extremely complex and Herod went to Rome via Rhodes to be interviewed by Anthony and Octavian. The Senate ratified Herod as King of Judaea and he returned to that country in 39 B.C.

His first wife was Doris, an Idumean woman and his second was Mariamme, granddaughter of the Ethnarch Hyrcanus. By Doris he had a son Antipater and by Mariamme two others Alexander and Aristobulus and also two daughters. He had eight other wives in all. Herod loved Mariamme passionately and jealously. She was beautiful but proud and cold and did not return his love. Mariamme was unjustly killed in 29 B.C. at the instigation of Herod's sister Salome on a trumped-up charge of attempted poisoning. Herod could not forget her and in his remorse and frustrated desire developed a psychotic illness. His physicians were unable to alleviate his condition and his recovery was slow.

During the seventh and last decade of his life, Herod aged greatly, became vacillatory and indecisive, impatient of opposition, goaded to excesses, ruthlessly severe and vindictively savage. Paranoid tendencies, always a weakness in his character, became very pronounced. In his last years he suffered many misfortunes, both politically and in his family life. His mind was poisoned against his two sons born to Mariamme and he charged Alexander and Aristobulus before Augustus in 12 B.C.; they were cleared by Augustus and reconciled to Herod, but further conspiracies by Salome and her brother Pheroras led to their execution in 7 B.C. Later, Antipater was also tried and imprisoned. Herod was now sinking fast; he went to Callirhoe and was treated by hot baths and immersion in warm oil. He attempted suicide with a fruit knife but was prevented from injuring himself. Soon after he had Antipater executed and survived him for only a few days. He died in March 4 B.C. He was succeeded by Archelaus as King and by Antipas and Philip as Tetrarchs.

\section{THE HEALTH OF THE KING}

As already indicated, Herod appears to have been paranoid during much of his life. After the execution of Mariamme, when he was already 44 years old, he suffered an illness of psychotic type. Herod had apparently been sexually much under the spell of Mariamme during the eight years of their marriage and after her death he suffered physical deprivation coupled with great remorse. He would frequently call out for her in a most unseemly or indecent manner.

Herod went into the desert to nurse his grief and there became very ill. He suffered from pain in the back of his head and his neck, coupled with madness. His physicians were unable to help him; medicines were valueless and his mental state precluded dietary treatment. This illness was almost certainly psychosomatic but he recovered very slowly. Although he lived for another twenty-six years he was never completely restored to his former state. He became progressively more moody, suspicious and vindictive until, as mentioned above, in the seventh and last decade of his life he aged very greatly and became indecisive, impatient of opposition, savage and increasingly paranoid.

HIS TERMINAL ILLNESS AND DEATH

Josephus gives an account of Herod's last illness and death in both Antiquities 


\section{The Last Illness of Herod the Great}

(VI:5) and War (I:5-I:7). The stories are consistent and to some extent complementary The symptoms may conveniently be summarised here.

Herod suffered from mild pyrexia, itching of the skin of the whole body, pain in the intestines, oedema of the feet and lower abdomen with some inflammation of the superficial tissues of the lower abdomen and gangrene of the genitalia on which

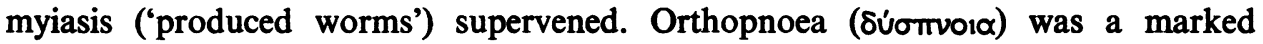
feature and tachypnoea also occurred. There were convulsive spasms in the limbs. Foetor of the breath was obvious. The accounts in Wars and Antiquities tally closely but itching is mentioned only in Wars and foetor only in Antiquities.

Translations by Lodge (1670), L'Estrange (1702), Whiston (1737), Traill (1851), Thackeray (1927), Williamson (1959) and Marcus and Wikgren (1963) have been compared. The modern translators (Thackeray, Williamson, Marcus and Wikgren) minimize the fever as did Traill but Lodge in Wars says a 'vehement ague', L'Estrange in Wars a 'violent fever' although in Antiquities he says the fever was a light one. Whiston translates in Wars a 'great fever' although in Antiquities a 'fire glowed in him slowly which did not so much appear to the touch outwardly as it augmented his pain inwardly'. Professor Joshua O. Leibowitz has, however, pointed out to me that, at a time when no clinical thermometry existed, it may be unwise to assume with certainty that the expressions used by Josephus were not, in fact, metaphorical only. There seems to me, nevertheless, no doubt that the ancients were well aware of the significance of fever.

Another discrepancy is in the nature of the dyspnoea. Whiston in Wars states that Herod 'could not breathe but when he sat upright' and in Antiquities 'when he sat upright he had difficulty in breathing'. Traill in Wars 'unable to breathe except in an upright posture'. Lodge in Wars says only 'tormented with difficulty of breath' and in Antiquities 'shortness of breath' and L'Estrange in Wars 'difficulty of breathing'

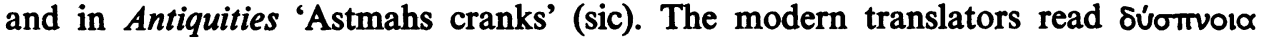
in the sense of orthopnoea. Thackeray (1927) in Wars translates 'asthma with great

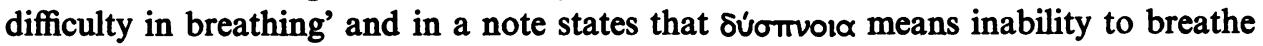
except in an upright posture. Williamson in Wars says a 'difficulty in breathing especially when lying down' and Marcus and Wikgren in Antiquities his constant 'gasping'.

Herod sought relief in the sweet water baths of Callirhoe at the North-East end of the Dead Sea. He was immersed in hot oil but fainted and appeared likely to die: his attendants created such an uproar that he was aroused. He later returned to Jericho in a melancholy state. He there developed a convulsive cough and showed evidence of lack of nourishment. He attempted suicide with a fruit knife but was prevented by his cousin: at this point he had his eldest son Antipater executed but Herod survived him by only five days. The king was buried with great pomp, according to his wishes, at Herodium.

\section{THE DIAGNOSIS}

The major symptoms in the case are orthopnoea and tachypnoea, oedema of the feet, genitalia and lower abdomen. These, occurring in a man who had in the seventh decade of life aged prematurely and became vacillatory, impatient and savage and 


\section{A. T. Sandison}

vindictive, would be consistent with progressive hypertensive arteriosclerosis. The arteriosclerotic process may affect the cerebral arteries; Price (1946) states that mental changes after the age of 60 years tend to indicate a higher probability of organic vascular disease than if they occur earlier. On the other hand, many unstable persons develop arterial disease in later life. The terminal orthopnoea, cough and oedema signal congestive cardiac failure. About $60 \%$ of patients with continuing hypertension manifest terminal congestive cardiac failure in contrast to approximately $30 \%$ who die as a result of cerebral haemorrhage.

Further, congestive failure may involve the liver and give upper abdominal pain. The oedema of the dependent parts may lead to cellulitis, ulceration and gangrene. In a warm country, myiasis might well supervene. I am assuming that the term 'produced worms' is not metaphorical; Professor Leibowitz argues that Herod would have had sufficient servants to keep flies away.

This type of myiasis is described by biologists as semi-specific or semi-obligate; in this dipterous larvae, normally occurring in decomposing organic matter, invade living tissues. In tropical and sub-tropical countries it is most important, especially in children and helpless adults, to protect all septic wounds or sores against flies. The clinician classifies this type of infestation as traumatic myiasis in which flies are attracted to wounds, ulcers and malodorous skin, regardless of location. The flies involved include Fannia, Piophila, Tubifera, Megaselia, Musca, Muscina and Sarcophaga species (Mackie, Hunter and Worth, 1945; Ash and Spitz, 1945).

Job's flesh was clothed with worms and clods of dust and his skin was broken and became loathsome (Job 7:5). In the Apocrypha it is said that Antiochus, son of Demetrius, was smitten by the Lord with pains in the bowels and fell from his chariot, all the members of his body being much pained. Worms rose up out of his body, his flesh fell away and the filthiness of his smell was noisome to all his army (II Macc. 9:1-29). It is worthy of note also that Herod Agrippa I, grandson of Herod the Great, died in somewhat similar circumstances to his grandfather in A.D. 44. He developed abdominal pain while at the theatre and died within five days. Meyshan (1959) believes that he was poisoned with arsenic but there seems little concrete evidence for this. Josephus does not mention myiasis in this case but in Acts (12:23) we read that 'he was eaten of worms'. I have discussed briefly elsewhere (Sandison, 1967a) the other evidence of myiasis in antiquity.

If we assume that Herod was indeed hypertensive then the remaining symptoms of his disease-pyrexia, itching, convulsive spasms in the limbs, inflammatory ulceration of the intestines-can all be explained by the supervention of uraemia as occurs in about $10 \%$ of cases of hypertension. The whole complex would therefore be one of cardio-renal failure. That this is a common disease is indicated by Wright's calculation that of 25 million people over the age of 50 years in the U.S.A., $60 \%$ or 15 million die of some aspect of cardiovascular-renal syndrome (Wright, 1952). I have discussed elsewhere (Sandison, 1962, 1967b) the evidence for degenerative vascular disease (some of which was due to hypertension) in antiquity and give reasons for believing that it was not uncommon, allowing for the fact that the relatively short expectation of life precluded its development in most persons.

A similar diagnosis of cardio-renal failure due to hypertension was made briefly 


\section{The Last Illness of Herod the Great}

by Manson in a note published in Perowne (1956). Manson further states that the symptoms of Herod's terminal illness are not unusual in untreated peasants of the Near East at the present time. Manson visualizes Herod as an aged arteriosclerotic becoming increasingly prone to mood changes, delusions of persecution, uncontrolled hypertensive cerebral attacks and even attempted suicide. Coincidentally, heart and kidney function deteriorates and dropsy develops affecting the lungs and causing breathlessness. Poisons accumulate and the mouth becomes ulcerated with foul breath; there is burning pain in the stomach, ulceration of the bowel and diarrhoea. The low grade fever is usual, dropsy increases, the liver becomes large and painful and the peritoneal cavity fills with fluid. The scrotum distends, becomes gangrenous and quickly is infested by maggots.

I am, of course, aware that dropsy may have causes other than congestive cardiac failure, e.g. portal hypertension resulting from hepatic cirrhosis. Here ascites causing dyspnoea and peripheral oedema may be conspicuous but in about two-thirds of such cases jaundice is likely at some time to be a feature and haematemesis is also common.

Professor Leibowitz has pointed out to me that Neuburger (1919) considered that Herod suffered from hepatic cirrhosis. This merits serious consideration. Professor Leibowitz agrees with this diagnosis although he concedes that arteriosclerosis was also present and wrote a letter to Dr. Abraham Schalit amplifying his view. Professor Leibowitz has provided me with an English translation of this letter, which follows:-

The description by Josephus of Herod's [last] illness is not to be explained medically in all particulars. The mental aberration, especially in his later years, can be explained as a kind of paranoia; also the psychopathic traits of his earlier years can be diagnostically precised.

Signs witnessing to liver disease [cirrhosis] or, more generally, to portal hypertension are: swelling of the feet and lower parts of the abdomen; the cutis of these parts dropsical, full of water; blood-circulation impaired with dyspnoea. The itching is well known in liver diseases, even without pronounced jaundice. The pains in the abdomen could be based on thromboses and are not occurring in uncomplicated cirrhosis. It seems probable that arteriosclerotic arterial disease was present in addition to the fatal liver disease; as it is well known, Neuburger described Herod's disease as liver cirrhosis.

The opinion expressed by S. Muntner (Korot I, p. 3-4, 1953) that the disease is "without any doubt' a case of diabetes has some symptoms to be based upon: the increased appetite, itching and ulceration of the male organ. Not explained by this diagnosis are: the swelling of the lower part of the body, and the lack of thirst, which is the most striking feature in a report by a layman. Whereas the assumption of liver cirrhosis together with that of arteriosclerotic vascular disease, and a hypothetical proposition of abdominal thrombosis, explain sufficiently the bodily condition, as far as the ancient account gives the description of the syndrome.

To: Dr. Abraham Schalit, *

The Hebrew University.

- Now Professor of Jewish History, Research Scholar in Jewish History of the second temple period.

Professor Adam Patrick has said to me that the symptoms, as described by Josephus, may point to a diagnosis of chronic amoebic dysentery. In the Antiquities (Whiston's translation) it is stated that 'the entrails were also exulcerated and the chief evidence of his pain lay in his colon'. Professor Patrick attaches importance to the abdominal pain and believes that the physicians of the time were familiar with such ulceration in the colon, probably amoebic in origin. 


\section{A.T. Sandison}

The oedema in the lower abdomen and lower limbs, complicated by myiasis, would, he thinks, probably be secondary to cardiac weakness. Professor Patrick also suspects that Herod had an amoebic abscess in his liver which had ulcerated through the diaphragm and which ultimately ruptured into a bronchus, leaving a bronchohepatic fistula.

All other diagnoses seem unlikely. Jones (1938), a layman, states of Herod-'He was in the final stages of disease, which from Josephus' lurid description appears to have been cancer of the bowels'. Such a diagnosis leaves unexplained the majority of Herod's symptoms and cannot be entertained.

Meyshan (1957) writing in Hebrew with only summaries in English and French, concludes that Herod suffered from a malignant tumour of the pancreas (perhaps an islet-cell tumour in the tail) with metastases to peritoneum and thorax and thrombosis of veins of the abdomen and lower extremities. This is ingenious but leaves quite unexplained several important symptoms and appears to be open to several objections.

The greatest frequency of islet-cell tumour is in the age group 30-50 years and it is in the lower age group that functional effects tend to occur; Herod was aged 70 years at his death. Moreover, only about $10 \%$ of islet-cell tumours show malignant propensity. Spread to thorax and peritoneum is rare. Further, the malignant variety is rather less likely to be functional than the benign (Anderson, 1957).

The major argument against this diagnosis, however, seems to me that to explain even a portion of Herod's symptomatology, functional islet-cell tumour would require to produce both hypoglycaemic hyperinsulinaemia as well as the less common ulcerogenic effect or so-called Zollinger-Ellison syndrome. The features of this latter syndrome are well described in a leading article in the Lancet (1963). The patient shows a typical, intractable peptic ulceration with extreme gastric hyperacidity and sometimes chronic diarrhoea of profuse watery type which leads to hypokalaemia and sometimes to bowel paralysis. But hyperinsulinism and the Zollinger-Ellison syndrome are quite separate entities.

Buhac (1963) writing briefly on the illness and death of Herod reviews the diagnoses made by some earlier writers. He states that Renan (1886) suggested poisoning and that this was acceptable to Preuss (1911). He also points out that Bennet diagnosed intestinal perforation with peritonitis complicating ascariasis, but Bennet (1896) refers here to Herod Agrippa and not to Herod the Great. Buhač himself suggests malignant disease of the abdomen, perhaps a pancreatic carcinoma. This diagnosis he makes on the basis of abdominal pain, oedema of the feet and scrotum, dyspnoea and later jaundice. In the accounts given by Josephus there is no evidence of jaundice and the diagnosis can scarcely stand. Buhač, however, rightly regards the myiasis as a complication due to the warm climate.

\section{CONCLUSION}

Thanks to the histories of Flavius Josephus, we can build up a detailed, and probably reliable, picture of the health, last illness and death of Herod the Great of Judaea. Herod was very probably a hypertensive who in the last decade of his life suffered from progressive cerebral arteriosclerosis. His death may have been due to a com- 


\section{The Last Illness of Herod the Great}

bination of congestive cardiac failure and terminal uraemia with traumatic myiasis of the genitalia. Alternative diagnoses which merit consideration are hepatic cirrhosis and amoebic dysentery.

\section{ACKNOWLEDGEMENTS}

I am grateful to Professor Adam Patrick, Emeritus Professor of Medicine and Lecturer in the History of Medicine at the University of St. Andrews, for helpful criticism of this manuscript.

Professor Joshua $\mathbf{O}$. Leibowitz made several important observations and graciously permitted me to quote the English translation of his letter of 7 July 1958 to Dr. Abraham Schalit of the Hebrew University. This was originally published in Hebrew in Dr. Schalit's book King Herod, Jerusalem, 1960.

\section{REFERENCES}

Anderson, W. A. D., (ed.), Pathology, 3rd ed., London, Kimpton, 1957.

AsH, J. E. and SpITZ, SOPHE, Pathology of Tropical Diseases: An Atlas, Philadelphia, Saunders, 1945.

BENNET, R., The Diseases of the Bible, London, Religious Tract Society, 1896.

BuHAč, I., 'Uber die Erkrankung und den Tod des Herodes', Dtsch. med. Wschr., 1963, 88, 287.

Flavius Josephus, translations into English:

L'Estrange, R., The Works of Flavius Josephus. Translated into English, London, Sare, 1702.

LoDge, T., The Famous and Memorable Works of Josephus, A Man of Much Honour and Learning among the Jews. Faithfully translated out of the Latin and French, London, 1670.

MARCuS, M. and WIrgren, A., Josephus with an English Translation, Vol. 8, Loeb Classical Library, London, Heinemann, 1963.

Thackeray, H. St. J., Josephus with an English Translation, Vol. 2, Loeb Classical Library, London, Heinemann, 1927.

Trallu, R., The Jewish War of Flavius Josephus. A new translation, 2 vols., London, Houlston and Stoneman, 1851.

Williamson, G. A., Josephus, The Jewish War, Translated, Harmondsworth, Penguin, 1953.

Whiston, W., The Works of Flavius Josephus, 1737. (Edition used, Edinburgh, Nelson, 1839).

Jones, A. H. M., The Herods of Judaea, Oxford, Clarendon Press, 1938.

'The Zollinger-Ellison syndrome', Lancet, 1963, 1, 367.

LeIBOWITZ, J. O., Personal communication, 1966.

MACKIE, T. T., Hunter, G. W. and Worth, C. B., A Manual of Tropical Diseases, Philadelphia, Saunders, 1945.

MeyshaN, J., 'The disease of Herod the Great, King of Judaea', (In Hebrew with summaries in English and French), Harefuah, 1957, 53, 154.

Idem., 'The disease of Agrippa the First, King of Judaea', (In Hebrew with summaries in English and French), Harefuah, 1959, 56, 118.

Manson, N., Note in Perowne, S., 1956.

NeUbURGER, M., Die Medizin in Flavius Josephus, Bad Reichenhall, Buchkunst, 1919.

PATrick, A., Personal communication, 1966.

PEROWNe, S., The Life and Times of Herod the Great, London, Hodder and Stoughton, 1956.

PrICE, F. W., (ed.), A Textbook of the Practice of Medicine, London, Oxford University Press, 1946.

Preuss, J., Biblisch-Talmudische Medizin, Berlin, Karger, 1911.

Renan, E., Les Apôtres, Paris.

SANDison, A. T., 'Degenerative vascular disease in the Egyptian Mummy'. Med. Hist., $1962,6,77$. 


\section{A.T. Sandison}

Sandison, A. T., (a) 'Parasitic diseases' in Diseases in Antiquity, Eds. Brothwell, D., and Sandison, A. T., Springfield, Thomas, 1967.

Sandison, A. T., (b) 'Degenerative vascular disease' in Diseases in Antiquity, Eds. Brothwell, D. and Sandison, A. T., Springfield, Thomas, 1967.

Thackeray, H. ST., J., Josephus: The Man and the Historian, New York, Jewish Institute of Religion Press, 1929.

Wright, I. S., Vascular Disease in Clinical Practice, 2nd ed., Chicago, Year Book Publishers. 1952. 